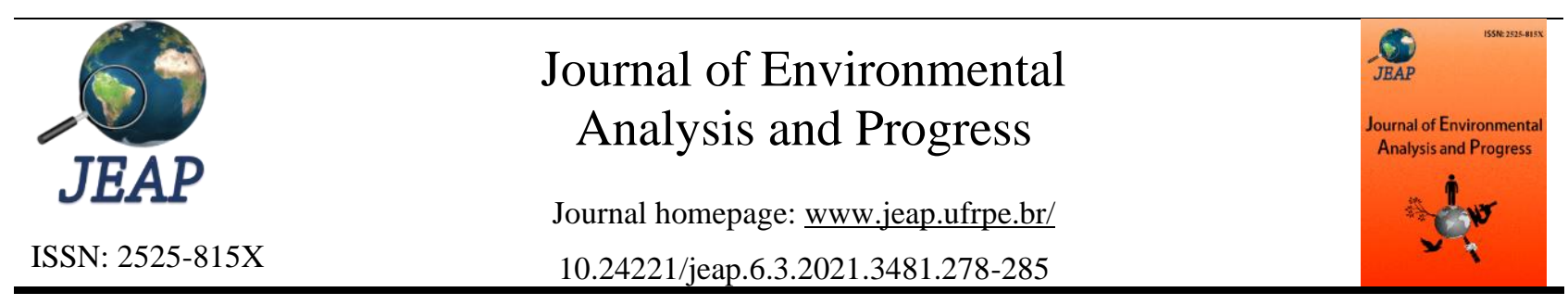

\title{
Antibacterial and coagulant potential of vegetable extracts in the alternative treatment of greywater
}

\author{
Lucas Victor Pereira de Freitas ${ }^{\mathrm{a}}$, Lucas David Rodrigues dos Santos ${ }^{\mathrm{a}}$, Bruna Emanuely Pereira \\ Freitas $^{\mathrm{b}}$, João Paulo Fernandes Tiago ${ }^{\mathrm{c}}$, Mônica Durães Braga ${ }^{\mathrm{b}}$ \\ ${ }^{a}$ Universidade de São Paulo-USP, Faculdade de Ciências Farmacêuticas de Ribeirão Preto-FCFRP. Av. do Café, s/n, \\ Campus da USP, Ribeirão Preto, São Paulo, Brasil. CEP: 14040-903. E-mail: lucasvictorfreitas@usp.br. \\ ${ }^{\text {b }}$ Faculdade Santo Agostinho-FASA. Av. Osmane Barbosa, n. 937, Conjunto Residencial J.K, Montes Claros, Minas \\ Gerais, Brasil. CEP: 39404-007. \\ c Universidade Federal de Minas Gerais-UFMG, Instituto de Ciências Agrárias. Av. Universitária, n. 1000, Bairro \\ Universitário, Montes Claros, Minas Gerais, Brasil. CEP: 39404-547.
}

\begin{tabular}{|c|c|}
\hline A R T I C L E I N F O & A B S T R A C T \\
\hline Received 14 May 2020 & The reuse of greywater $(\mathrm{GW})$ from some domestic activities is considered a \\
\hline Accepted 14 Sep 2021 & sustainable technique for water-saving; however, GW has high turbidity and \\
\hline Published 18 Sep 2021 & bacteriological load. Therefore, this study aimed to evaluate the use of extracts \\
\hline & obtained from Citrus aurantifolia (Christm.) Swingle in the alternative treatment of \\
\hline & GW, aiming at reducing turbidity and bacteriological load. Extracts obtained from \\
\hline & methods. Posteriorly, they were applied to GW samples, monitoring the turbidity and \\
\hline & heterotrophic bacteria at different time intervals. All extracts showed coagulant and \\
\hline & antibacterial properties, reducing turbidity $(39-88 \%)$ and heterotrophic bacteria (66- \\
\hline & $93 \%$ ) after $24 \mathrm{~h}$ of the treatment. The plant extracts become an alternative for use in \\
\hline & $\begin{array}{l}\text { GW reuse systems instead of synthetic chemical agents, with biodegradability, ease } \\
\text { of access, and low toxicity of the sludge generated. }\end{array}$ \\
\hline & Keywords: Turbidity, heterotrophic bacteria, natural products. \\
\hline
\end{tabular}

\section{Introduction}

Water is an essential natural resource not only for a state or a country but for the entire humanity (Dhamodharan et al., 2019). The accomplishment of anthropic activities is directly related to water availability, a propulsive aspect of local and regional development. Water has become the strategic resource in any country due to population growth, urbanization, industrialization, agriculture, and electric power production (Santos et al., 2018). Adequate quantity and quality, water resources provide a precondition for economic development and ecological integrity (Pejman et al., 2009; Wu et al., 2018).

However, water source degradation, mainly due to its inefficient and excessive use, makes water availability insufficient for the processes in which it is required. As Couto et al. (2015) discussed, water scarcity tends to rise due to the increasing demand for water resources to meet the population's needs.

Studies on water reuse have been intensified, highlighting the reuse of greywater as an alternative source (Blanky et al., 2015). Greywater (GW) is defined such as effluent derived from domestic activities originating from residential clothes washers, bathtubs, showers, bathroom sinks, and laundry machines (Oron et al., 2014), and that does not have the contribution of sanitary basins and kitchen sinks, as these sources contain many polluting compounds. With the limited amount of water available, measures should be proposed to use this natural resource better.

Reusing GW is expected to bring a significant reduction in domestic water demand and maximize the exploitation efficiency of this scarce or restricted resource on-site (Ghisi \& Ferreira, 2007). GW has the potential to be used for irrigation and toilet flushing, or it can be reused for ornamental, garden, and lawn watering subject to GW treatment and its' quality level (Oron et al., 2014).

However, GW has a high turbidity characteristic and presents microorganisms responsible for the bad odor generated in the reuse 
systems, which may represent risks to users (Chen et al., 2013).

The total solids responsible for turbidity in the water serve as shelters for microorganisms, pathogenic. The presence of pathogens is the main public health risk arising from the reuse of GW. The pathogenic microorganisms include bacteria, protozoa, viruses, and parasites, where some concentrations are high enough to enforce health risks (Oron et al., 2014). These parameters strengthen the recommendation of treating $\mathrm{GW}$ before its use. (Al-Jayyousi 2003; Eriksson et al., 2002).

The removal or reduction of turbidity and microorganisms is usually accomplished by using synthetic chemicals, which have some disadvantages. For the removal of turbidity, aluminum sulfate $\left(\mathrm{Al}_{2}\left(\mathrm{SO}_{4}\right)_{3}\right)$ and ferric chloride $\left(\mathrm{FeCl}_{3}\right)$ are usually used. Despite efficient coagulants, these products generate nonbiodegradable sludges that need to be disposed of in specific landfills (Skoronski et al., 2014). For disinfection, chlorine is commonly used. However, chlorine may form carcinogenic organochlorine compounds in organic matter, such as trihalomethanes (Serodes et al., 2003).

Therefore, there is a need for sustainable alternatives, using natural products, which present efficiency, advantages, and benefits concerning the synthetic chemicals usually used, such as the low toxicity of the sludge generated, biodegradability, ease of access, and low financial cost.

The epicarp of the vegetables of the genus Citrus has many secondary metabolites, which are less frequent in other plants, presenting wide bioactivity when present in extracts. Because of that, the use of vegetal extracts becomes an alternative in conventional processes of $\mathrm{GW}$ treatment.

Citrus aurantifolia is a species that belongs to the family Rutaceae that has about 150 genera and 1600 species that are broadly distributed in tropical, subtropical, and temperate zones around the world (Lemes et al., 2018). Citrus aurantifolia (Christm.) Swingle, popularly known as lime, has several properties described in the literature, such as astringent, antibiotic, antiseptic, and antibacterial (Lee et al., 2018; Vendruscolo et al., 2005). However, to the best of our knowledge, no studies have been found in the literature to assess this fruit's coagulant and antibacterial activity in the alternative treatment of GW.
Thus, this study aimed to use extracts obtained from C. aurantifolia (Christm.) Swingle, for the removal of bacteria and reduction of turbidity in GW.

\section{Material and Methods \\ Samples collection}

In sterile $1 \mathrm{~L}$ glass bottles, wastewater samples were collected in residence with a GW reuse system from the washing machine, bath, and bathroom sink. The system does not have pretreatment.

\section{Preparation of vegetable extracts}

To obtain the extracts from the $C$. aurantifolia (Christm.) Swingle, the epicarp (peels), mesocarp (white part), endocarp (pulp), and the whole fruit were used. The fruits were obtained in the local commerce, considering that it is the main form of acquisition of this vegetal by the consumers. Extracts were obtained through boiling, rotavaporization of the hydroalcoholic extract, and pulverization. Extracting by the boiling method, $10 \mathrm{~g}$ of each part of the fruit were weighed in an analytical balance, transferred to a beaker with $100 \mathrm{~mL}$ of distilled water, and subjected to the boiling process for $15 \mathrm{~min}$.

Extracting by rotavaporization of the hydroalcoholic extracts, $10 \mathrm{~g}$ of each part of the fruit and $100 \mathrm{ml}$ of $70 \%$ ethanol (extractor solvent) were added in a glass flask. The flask was then hermetically sealed and kept rest for $72 \mathrm{~h}$. After, the aqueous fraction was subjected to the rotavaporization process until the organic solvent (ethanol) was completely evaporated.

Extracting by the pulverization process, 10 $\mathrm{g}$ of each fruit part were oven-dried at $50^{\circ} \mathrm{C}$, for 48 h. After drying, all parts were reduced to a fine powder. The solutions of each extract were then filtered and stores in a sterile glass flask.

\section{Application of vegetable extracts and statistical analysis}

The experiments were performed in three independent replicates in a completely randomized design. The obtained extracts were applied in 500 $\mathrm{mL}$ of GW samples. The description of the samples with the respective treatment submitted is presented in Table 1. We also analyzed a sample where the treatment was carried out by applying sodium hypochlorite $10 \%$, usually used in water reuse systems. A control sample corresponding to $\mathrm{GW}$ without any treatment was analyzed (Table 1 ). 
Table 1. Description of the samples with the respective treatment submitted. Font: Freitas et al. (2020).

\begin{tabular}{cll}
\hline Description of samples & Treatment submitted & $\begin{array}{c}\text { Quantity } \\
\text { applied }\end{array}$ \\
\hline 1 & GW + Extract hydroalcoholic epicarp & $10.0 \mathrm{~mL}$ \\
2 & GW + Extract hydroalcoholic mesocarp & $10.0 \mathrm{~mL}$ \\
3 & GW + Extract hydroalcoholic endocarp & $10.0 \mathrm{~mL}$ \\
4 & GW + Extract hydroalcoholic whole fruit & $10.0 \mathrm{~mL}$ \\
5 & GW + Extract boiling epicarp & $10.0 \mathrm{~mL}$ \\
6 & GW + Extract boiling mesocarp & $10.0 \mathrm{~mL}$ \\
7 & GW + Extract boiling endocarp & $10.0 \mathrm{~mL}$ \\
8 & GW + Extract boiling whole fruit & $10.0 \mathrm{~mL}$ \\
9 & GW + Extract pulverization epicarp & $5.0 \mathrm{~g}$ \\
10 & GW + Extract pulverization mesocarp & $5.0 \mathrm{~g}$ \\
11 & GW + Extract pulverization endocarp & $5.0 \mathrm{~g}$ \\
12 & GW + Extract pulverization whole fruit & $5.0 \mathrm{~g}$ \\
13 & GW + Sodium hypochlorite 10\% & $10.0 \mathrm{~mL}$ \\
14 & Control sample (GW) & - \\
\hline
\end{tabular}

For the statistical analysis of the data, we used the software $\mathrm{R}^{\circledR}$ 3.6.0. The means of the results of the treatments were compared by the Scott-Knott test at the level of $5 \%$ of significance. The means of the treatments, including the control, were compared by the Dunnet test at the $5 \%$ level of significance.

\section{Analysis, turbidity, and heterotrophic bacteria}

The analysis of the efficiency of the treatment was made at different times. The turbidity of the samples was analyzed in periods of $1 \mathrm{~h}, 6 \mathrm{~h}, 12 \mathrm{~h}$, and $24 \mathrm{~h}$ after starting treatment. For the analysis of the turbidity parameter, the digital turbidimeter Policontrol Ap 2000® was used.

After $24 \mathrm{~h}$ of the extracts and sodium hypochlorite $10 \%$ application, the parameter of heterotrophic bacteria in the samples was performed using the pour plate method, according to the methodology defined in standard methods for water and wastewater (ALPHA 2012). Briefly, $1 \mathrm{~mL}$ of the sample was added to a sterile petri dish. Next, the R2A agar culture medium was added. The mixture was homogenized and incubated at 37 ${ }^{\circ} \mathrm{C}$ for $48 \mathrm{~h}$. After this period, we counted the colony-forming units (CFU's). The procedure was performed in triplicate, and the mean of CFU's was calculated.

\section{Results and Discussion}

Turbidity analysis

The turbidity analyzes showed that all extracts from the $C$. aurantifolia (Christm.)
Swingle showed efficiency in reducing this parameter in the GW samples at times analyzed since there was a comparison with the initial turbidity value in the control sample. The means of the results at $1,6,12$, and $14 \mathrm{~h}$ after the treatments and the results of the statistical tests are presented in Figure 1.

It was verified that the turbidity of the control sample presented an initial value of 139.1 nephelometric turbidity unit (NTU), having a reduction of this parameter in the analyzed times of 1, 6, 12, and $24 \mathrm{~h}$ (Figure 1). After $24 \mathrm{~h}$, the turbidity of the control sample was reduced to 117.0 NTU, a reduction of approximately $16 \%$ compared to the initial value, being lower than the turbidity of the samples exposed to the treatment of the vegetal extracts. A turbidity reduction is expected since all analyzed samples were kept rest, resulting in the sedimentation of suspended solids present in the sample, allowing the consequent decrease in turbidity.

Analyzing the results of GW samples submitted to treatment with the hydroalcoholic extracts (Figure 1), it is observed that the most efficient in reducing turbidity was the hydroalcoholic extract obtained from the whole fruit (sample 4), which was presented, after $24 \mathrm{~h}$ of application, $65 \%$ of turbidity removal when compared to the initial value of the control sample (139.1 NTU). Similarly, the other extracts obtained by this extraction method (samples 1,2, and 3) had efficiencies close to $60 \%$. 

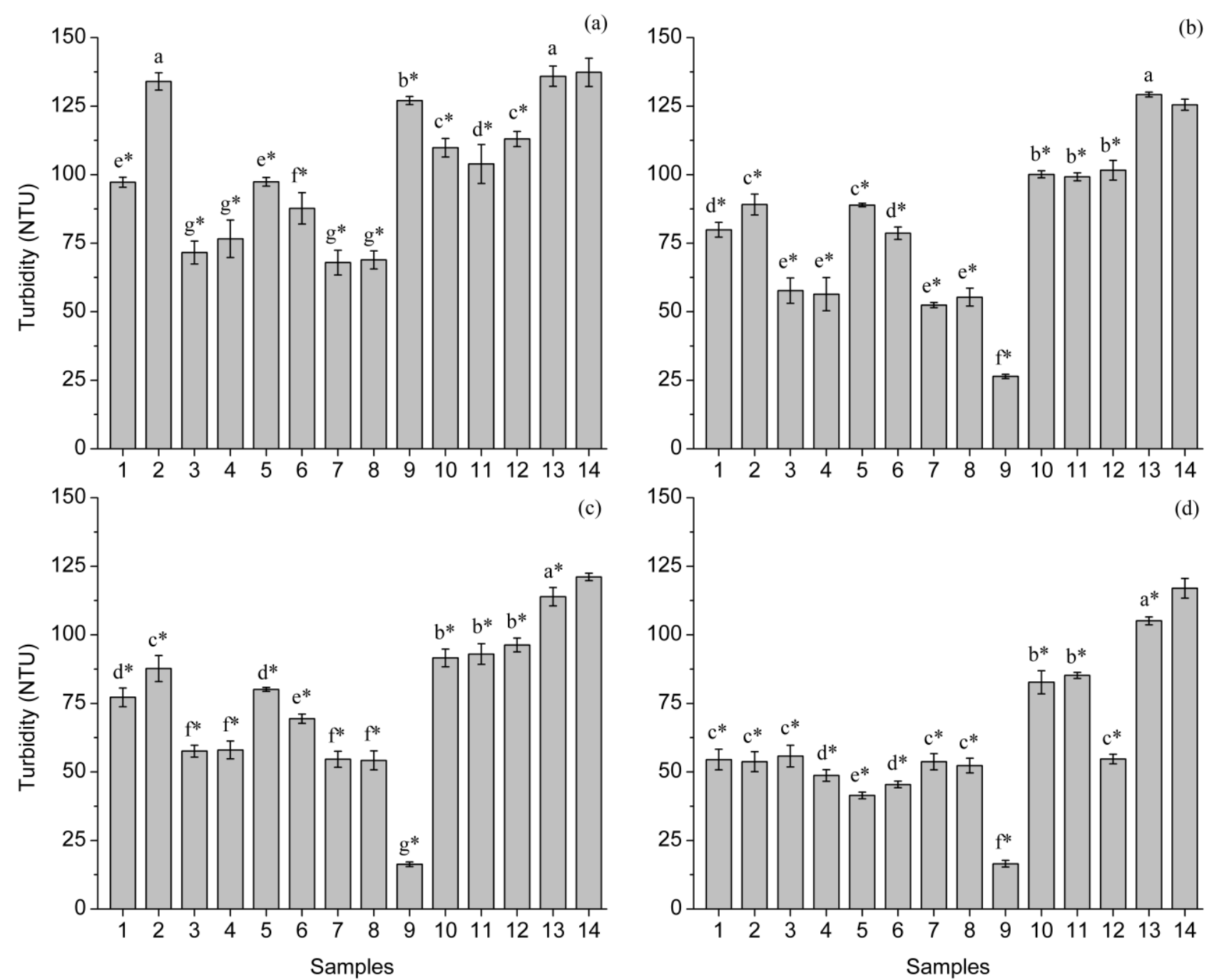

Figure 1. Turbidity values at distinct periods after treatments: a. 1 h; b. 6 h; c. 12 h; d. 24 h. Means accompanied by the same letter do not statistically differ between treatments by the Scott-Knott test at a $5 \%$ significance level. Font: Freitas et al. (2021).

The epicarp and mesocarp boiling (sample 5 and 6) were the most efficient by this extraction method, with a removal percentage of 70 and $67 \%$, respectively, after $24 \mathrm{~h}$ of application in the GW sample. The remaining extracts obtained from the endocarp boiling (sample 7) and of the whole fruit (sample 8) were efficient to removal the turbidity, approximately $62 \%$, after $24 \mathrm{~h}$ of the beginning of the treatment (Figure 1).

Samples from extracts obtained by the pulverization showed that the extract of the epicarp (sample 9) was highly efficient to removal the turbidity, approximately $88 \%$ of reduction after 12 and $24 \mathrm{~h}$ of the application of the extract. Extracts from pulverization were also efficient, reducing the turbidity at whole fruit pulverization extracts (sample 12), mesocarp (sample 10), and endocarp (sample 11), with removal percentages of $60 \%$, $41 \%$, and $39 \%$, respectively (Figure 1). In general, the extracts obtained by this method did not obtain high turbidity removal rates in the first hour of the application. This fact is due to the extracts being constituted of a fine powder that increases the number of suspended solids, responsible for the increase of turbidity when applied in the water sample. After a few hours of application, the extracts acted to remove the turbidity of the GW samples.

The turbidity showed a progressive reduction in sodium hypochlorite $10 \%$, and after a period of $24 \mathrm{~h}$ a percentage of removal of approximately $24 \%$, corresponding to 105.1 NTU, was obtained. Despite reducing turbidity, the sodium hypochlorite did not present efficiency compared to the vegetal extracts, with a mean of $60 \%$ turbidity removal rate. Scott-Knott test at the $5 \%$ level of significance showed that the treatment was statistically different from the other treatments.

Lo Monaco et al. (2010) tested the Moringa oleifera seed extract in samples of domestic sewage, obtaining $35.3 \%$ of turbidity removal after $24 \mathrm{~h}$ of treatment with the extracts. 
Furthermore, a comparative study of natural coagulant effectiveness (Moringa oleifera and hydrolyzed cassava), extracts and artificial coagulant (alum) for the treatment of domestic wastewater, concluded that it, despite residual and health implications, can be successfully replaced, partially or wholly, by natural coagulants (Ugwu et al., 2017).

The most used coagulants for the treatment of water are aluminum sulfate $\left(\mathrm{Al}_{2}\left(\mathrm{SO}_{4}\right)_{3}\right)$ and ferric chloride $\left(\mathrm{FeCl}_{3}\right)$. Nevertheless, there is a large generation of sludge during the coagulation process, leading to a concern regarding its disposal (Paula et al., 2016). Thus, the use of plant extracts in the alternative treatment of water has been discussed because of having advantages over the synthetic chemicals usually employed, highlighting the lower financial cost, ease of access, biodegradability, and low toxicity of the sludge generated.

\section{Analysis of heterotrophic bacteria}

After $48 \mathrm{~h}$ of incubation, colony-forming units (CFUs) were counted in the plates, performed in triplicate, and calculated the mean values. In the analysis of heterotrophic bacteria, it was verified that all the extracts were efficient in bacterial removal, as can be seen in Figure 2.

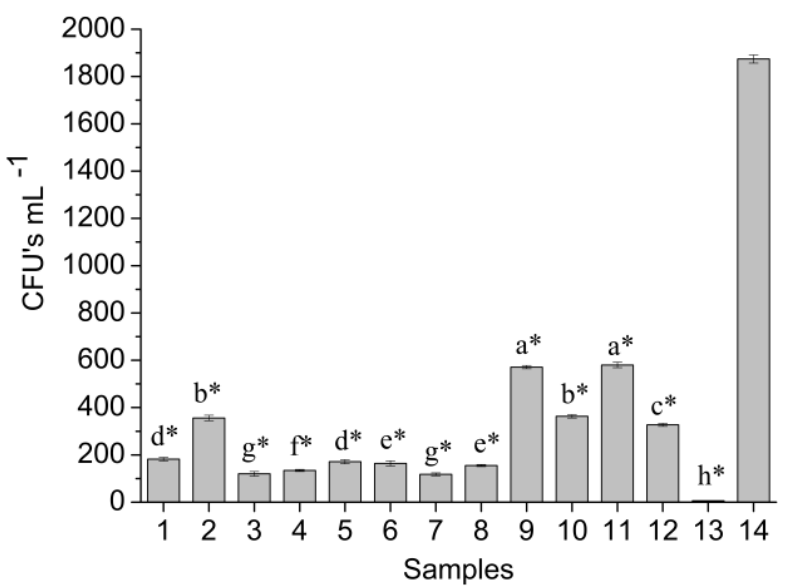

Figure 2. Amount of heterotrophic bacteria analysis in plant extracts. Means accompanied by the same letter do not statistically differ between treatments by the Scott-Knott test at a 5\% significance level. Font: Freitas et al. (2021).

The control sample (sample 14) resulted in 1874 CFUs $\mathrm{mL}^{-1}$, indicating a sizeable bacteriological presence in the sample. A high concentration of microorganisms in $\mathrm{GW}$ is undesirable since there may be pathogenic organisms, implying risks to the users' health. This result is expected since the high value of heterotrophic bacteria in $\mathrm{GW}$ is directly related to the origin of this effluent, derived from bathing, washing clothes, and general cleaning, which are sources of water contamination. Pathogens potentially found in $\mathrm{GW}$ originate from three main sources: fecal contamination, peripheral pathogens (e.g. skin and mucous tissue), and those stemming from food handling (Maimon et al., 2010). So, alongside its benefits, $\mathrm{GW}$ reuse might pose some risks (Maimon et al., 2014).

Bad odor from GW stock systems is a factor directly related to bacterial activity. GW is rapidly decomposed by the microorganisms, consuming the available oxygen in the medium causing anaerobic conditions. Under these conditions, the degradation of organic matter leads to the release of gases responsible for the bad odor of the system.

The bacteriological removal rates described were obtained from comparing with the number of CFUs of the control sample (1874 CFU's). The sample treated with sodium hypochlorite $10 \%$ (sample 13) was the one that obtained the highest bacteriological removal, with an average of only six CFUs, which equals a removal rate of $99.7 \%$ compared to the control sample (Figure 2). This result is expected because chlorine is the most widely used product in the world for conventional disinfection.

The samples with extracts obtained by the pulverization of the epicarp (sample 9) and endocarp (sample 11) applied were the ones that presented the smallest reduction of CFU's number, with a removal rate close to $70 \%$. Extract samples from rotavaporization of mesocarp hydroalcoholic extract (sample 3), mesocarp pulverization (sample 10), and whole fruit pulverization (sample 12) presented a bacterial removal efficiency of around $80 \%$ (Figure 2).

The samples came from epicarp, endocarp, and whole fruit hydroalcoholic, boiling extracts (samples 1, 2, 4, 5, 7, and 8), and the sample treated with the mesocarp boiling extract (sample 6) were those with a high rate of bacterial removal, and removal percentage higher than $90 \%$, (Figure 2).

Previous studies indicate that $C$. aurantifolia presents in its composition oleic acid, palmitic acid, citral, and 4-Hexen-3 one, which demonstrated antibacterial activities (Boyanova 2014; Liu et al., 2012; Mahadwar et al., 2015; Sandoval-Montemayor et al., 2012; Sumer et al., 2013). Several studies have tested $C$. aurantifolia extracts against bacterial strains and showed significant effectiveness in inhibiting bacterial growth (Gerhardt et al., 2012; Lee et al., 2018; Tomotake et al., 2006). Furthermore, studies evidenced that the oil of $C$. aurantifolia presented expressive antimicrobial properties against fungal strains (Castro, 2012). 
The sodium hypochlorite showed high efficiency at bacteriological removal to vegetable extracts, but it has drawbacks. When organic matter and other precursors in water react with chlorine, several disinfection by-products (DBPs) are formed, such as trihalomethanes (THMs) (Serodes et al., 2003). It may cause risks to users since long-term exposure to THMs is of concern due to possible cancer risks and other chronic health effects (WHO, 2005). Thus, it is nonetheless desirable to minimize THMs in water (Werner et al., 2016).

For all these reasons, there is a tendency to replace chlorine and other synthetic chemical agents used in water treatment. Therefore, the use of vegetal extracts is an alternative due to the antibacterial efficiency and biodegradability of the generated sludge.

\section{Conclusion}

All extracts obtained from C. aurantifolia (Christm.) Swingle presented coagulant and antibacterial properties, reducing turbidity (39$88 \%)$ and heterotrophic bacteria (66-93\%) after 24 $\mathrm{h}$ of the treatment. In general, it is verified that the extracts obtained by the extraction methods of boiling and rotavaporization presented superior advantages to the extracts obtained by the pulverization, especially in bacterial removal. There was no significant variation in the results using the different parts of the fruit. In this sense, we recommended using the whole fruit to produce the extracts.

Thus, according to the results, the extracts from C. aurantifolia (Christm.) Swingle may be an alternative for use in greywater treatment systems, replacing synthetic chemical agents, presenting advantages such as low cost, ease of access, biodegradability, and low toxicity of the generated sludge. Notably, it is the first application of $C$. aurantifolia extracts for this purpose reported in the scientific literature.

\section{References}

APHA. 2012. Standard methods for the examination of water and wastewater, 22nd ed. In: Rice, E. W. R. B.; Eaton, D.; Clesceri, L. S. (Eds.). American Public Health Association (APHA), American Water Works Association (AWWA) and Water Environment Federation (WEF), Washington, D.C., USA.

Al-Jayyousi, O. R. 2003. Greywater reuse: Towards sustainable water management. Desalination, 156, 181-192. DOI: 10.1016/S0011-9164(03)00340-0
Blanky, M.; Rodríguez-Martínez; S.; Halpern, M.; Friedler, E. 2015. Legionella pneumophila: From potable water to treated greywater; quantification and removal during treatment. Science of The Total Environment, 533, 557565. DOI: $10.1016 /$ j.scitotenv.2015.06.121

Boyanova, L. 2014. Comparative evaluation of the activity of plant infusions against Helicobacter pylori strains by three methods. World Journal of Microbiology and Biotechnology, 305, 1633-1637. DOI: 10.1007/s11274-013-1589-5

Castro, R. D. de. 2012. Screening da atividade antifúngica de óleos essenciais sobre cepas de candida. Pesquisa Brasileira em Odontopediatria e Clínica Integrada, 11, (3), 341-345. DOI: 10.4034/PBOCI.2011.113.06

Chen, Z.; Ngo, H. H.; Guo, W. 2013. A critical review on the end uses of recycled water. Critical Reviews in Environmental Science and Technology, 4314, 1446-1516. DOI: 10.1080/10643389.2011.647788

Couto, E. de A. do; Calijuri, M. L.; Assemany, P. P.; Santiago, A. da F.; Lopes, L. S. 2015. Greywater treatment in airports using anaerobic filter followed by UV disinfection: An efficient and low cost alternative. Journal of Cleaner Production, 106, 372-379. DOI: 10.1016/j.jclepro.2014.07.065

Dhamodharan, A.; Abinandan, S.; Aravind, U.; Ganapathy, G. P.; Shanthakumar, S. 2019. Distribution of metal contamination and risk indices assessment of surface sediments from Cooum river, Chennai, India. International Journal of Environmental Research, 13, 853860. DOI: 10.1007/s41742-019-00222-8

Eriksson, E.; Auffarth, K.; Henze, M.; Ledin, A. 2002. Characteristics of grey wastewater. Urban Water, 4, 85-104. DOI: 10.1016/S1462-0758(01)00064-4

Gerhardt, C.; Wiest, J. M.; Girolometto, G.; Silva, M. A. S. da; Weschenfelder, S. 2012. Aproveitamento da casca de citros na perspectiva de alimentos: Prospecção da atividade antibacteriana. Brazilian Journal of Food Technology, 15, 11-17. DOI: 10.1590/S1981-67232012005000033

Ghisi, E.; Ferreira, D. F. 2007. Potential for potable water savings by using rainwater and greywater in a multi-storey residential building in southern Brazil. Building and Environment, 42, 2512-2522. DOI: 10.1016/j.buildenv.2006.07.019

Lee, S. M.; Park, S. Y.; Kim, M. J.; Cho, E. A.; Jun, C. H.; Park, C. H.; Kim, H. S.; Choi, S. K.; Rew, J. S. 2018. Key lime (Citrus aurantifolia) inhibits the growth of triple 
drug-resistant Helicobacter pylori. Gut Pathogens, 10, 16-22. DOI: 10.1186/s13099018-0244-y

Lemes, R. S.; Alves, C. C. F.; Estevam, E. B. B.; Santiago, M. B.; Martins, C. H. G.; Santos, T. C. L. D.; Crotti, A. E. M.; Miranda, M. L. D. 2018. Chemical composition and antibacterial activity of essential oils from Citrus aurantifolia leaves and fruit peel against oral pathogenic bacteria. Anais da Academia Brasileira de Ciências, 90, 12851292. $\quad$ DOI: $\quad 10.1590 / 0001-$ 3765201820170847

Liu, Y.; Heying, E.; Tanumihardjo, S. A. 2012. History, global distribution, and nutritional importance of citrus fruits. Comprehensive Reviews in Food Science and Food Safety, 11, 530-545. DOI: $10.1111 / \mathrm{j} .1541-$ 4337.2012.00201.x

Lo Monaco, P. A. V.; Matos, A. T. de; Ribeiro, I. C. A.; Nascimento, F. da S.; Sarmento, A. P. 2010. Use of extract of moringa seeds as coagulant agent in treatment of water supply and wastewater. Ambiente e Agua - An Interdisciplinary Journal of Applied Science, 5, 222-231. DOI: 10.4136/ambi-agua. 164

Mahadwar, G.; Chauhan, K. R.; Bhagavathy, G. V.; Murphy, C.; Smith, A. D.; Bhagwat, A. A. 2015. Swarm motility of Salmonella enterica serovar Typhimurium is inhibited by compounds from fruit peel extracts. Letters in Applied Microbiology, 60, 334-340. DOI: 10.1111/lam.12364

Maimon, A.; Tal, A.; Friedler, E.; Gross, A. 2010. Safe on-site reuse of greywater for irrigation - A critical review of current guidelines. Environmental Science \& Technology, 44, 3213-3220. DOI: 10.1021/es902646g

Maimon, A.; Friedler, E.; Gross, A. 2014. Parameters affecting greywater quality and its safety for reuse. Science of The Total Environment, 487, 20-25. DOI: 10.1016/j.scitotenv.2014.03.133

Oron, G.; Adel, M.; Agmon, V.; Friedler, E.; Halperin, R.; Leshem, E.; Weinberg, D. 2014. Greywater use in Israel and worldwide: Standards and prospects. Water Research, 58, 92-101. DOI: 10.1016/j.watres.2014.03.032

Paula, H. M. de; Ilha, M. S. de O.; Andrade, L. S. 2016. Chemical coagulants and moringa oleifera seed extract for treating concrete wastewater. Acta Scientiarum. Technology, 38, 57-63. DOI: 10.4025/actascitechnol.v38i1.25699

Pejman, A. H.; Bidhendi, G. R. N.; Karbassi, A. R.; Mehrdadi, N.; Bidhendi, M. E. 2009. Evaluation of spatial and seasonal variations in surface water quality using multivariate statistical techniques. International Journal of Environmental Science \& Technology, 6, 467-476. DOI: 10.1007/BF03326086

Sandoval-Montemayor, N. E.; García, A.; Elizondo-Treviño, E.; Garza-González, E.; Alvarez, L.; Del Rayo, M. C. 2012. Chemical composition of hexane extract of Citrus aurantifolia and anti-mycobacterium tuberculosis activity of some of its constituents. Molecules, 17, 11173-11184. DOI: 10.3390/molecules170911173

Santos, R. C. L.; Lima, A. S.; Cavalcanti, E. B.; Melo, C. M. de; Marques, M. N. 2017. Aplicação de índices para avaliação da qualidade da água da Bacia Costeira do Sapucaia em Sergipe. Engenharia Sanitaria e Ambiental, 23, 33-46. DOI: 10.1590/s141341522017159832

Sérodes, J. B.; Rodriguez, M. J.; Li, H.; Bouchard, C. 2003. Occurrence of THMs and HAAs in experimental chlorinated waters of the Quebec City area (Canada). Chemosphere, 51, 253-263. DOI: 10.1016/S00456535(02)00840-8

Skoronski, E.; Niero, B.; Fernandes, M.; Alves, M. V.; Trevisan, V. 2014. Estudo da aplicação de tanino no tratamento de água para abastecimento captada no rio Tubarão, na cidade de Tubarão, SC. Ambiente e Agua An Interdisciplinary Journal of Applied Science, 9, 679-687. DOI: 10.4136/ambiagua. 1303

Sumer, Z.; Yildirim, G.; Sumer, H.; Yildirim, S. 2013. Cytotoxic and antibacterial activity of the mixture of olive oil and lime cream in vitro conditions. African Journal of Traditional, Complementary and Alternative Medicines, 10, 137-143. DOI: 10.4314/ajtcam.v10i4.22

Tomotake, H.; Koga, T.; Yamato, M.; Kassu, A.; Ota, F. 2006. Antibacterial activity of citrus fruit juices against vibrio species. Journal of Nutritional Science and Vitaminology, 52, 157-160. DOI: 10.3177/jnsv.52.157

Ugwu, S. N.; Umuokoro, A. F.; Echiegu, E. A.; Ugwuishiwu, B. O.; Enweremadu, C. C. 2017. Comparative study of the use of natural and artificial coagulants for the treatment of sullage (Domestic wastewater). Cogent Engineering, 4, 1365676. DOI: 10.1080/23311916.2017.1365676

Werner, D.; Valdivia-Garcia, M.; Weir, P.; Haffey, M. 2016. Trihalomethanes formation in point of use surface water disinfection with chlorine or chlorine dioxide tablets: Trihalomethanes formation in point of use 
water disinfection. Water and Environment Journal, $\quad 30, \quad 271-277$. DOI: 10.1111/wej.12209

WHO, World Health Organization. 2005. Trihalomethanes in Drinking-Water: Background Document for Development of WHO Guidelines for Drinking Water Quality. Geneva, World Health Organization.
Wu, Z.; Wang, X.; Chen, Y.; Cai, Y.; Deng, J. 2018. Assessing river water quality using water quality index in Lake Taihu Basin, China. Science of The Total Environment, 612, 914-922. DOI: 10.1016/j.scitotenv.2017.08.293 